\title{
ALTERNATÍV MÓDSZEREK ÉS ESZKÖZÖK AZ ÖKOISKOLÁBAN
}

\section{Csenger Lajosné}

NYME Öveges Kálmán Gyakorló Általános Iskola

\section{Bevezető}

$\mathrm{Az}$ életet biztosító bioszféra folyamatosan pusztul az emberi tevékenység következtében. Folyamatosan csökken a természetközeli területek aránya bolygónk felszínén.

A modernkori társadalmak környezetre gyakorolt hatásai, melyek a globális felmelegedés, a biodiverzitás csökkenése, a természeti erőforrások kimerülése, a folyamatosan növekvő hulladékhegyek, a vegyi anyagok fokozott használata formájában jelentkeznek komoly fenyegetést jelentenek bolygónk és az emberiség számára egyaránt.

A természet, a gazdaság és a társadalom válságos helyzete a természeti rendszerek dinamikus egyensúlyát és az arra épülő civilizáció létét is veszélybe sodorhatja. Amikor arra keressük a választ, hogy e helyzet kialakulásáért ki a felelős, hajlamosak vagyunk az ipart, a kormányzatot, a politikát hibáztatni és elfelejtjük, hogy mi emberek - életmódunkkal, cselekedeteinkkel - nagymértékben hozzájárulunk környezetünk rombolásához. Napi szokásainkon csak apró változtatásokat kellene végrehajtanunk és a mindennapi tevékenységeink módját kellene helyesebben és tudatosabban megválasztanunk ahhoz, hogy környezetünket kevésbé terheljük.

\section{A fogyasztói társadalom}

A XX. század hatalmas arányú mennyiségi és minőségi fejlődést eredményezett, amit az emberi tevékenység sikereként könyvelhetünk el, ám ez a sikertörténet elhalványítja az emberiség felelősségérzetét. Az ipari termelés növekedése hatalmas mennyiségü, pótolhatatlan természeti tőke felhasználása árán valósulhatott meg. Ha figyelembe vesszük, hogy a modern felfogás alapja az egyetemes jólét, amely nem ismeri a lemondást az áldozathozatal, csak azt hirdeti, hogy az ember akkor igazán boldog, ha gazdag, és minél gyorsabban szerzi meg mindazt, amire szüksége lesz annál boldogabb lesz, érthetővé válik, hogy alapvető célként fogalmazódott meg a termelés és a fogyasztás mértéktelen növelése.

A globalizáció és a technológiai fejlődés nyomán kialakult a fogyasztói társadalom. Ebben a jóléti - fogyasztói társadalomban a viszonylagos jólét ellenére vannak hajléktalanok, bünözők, prostituáltak, kisebbségek, ám az emberek többsége a mai értelemben véve emberi körülmények között élhet. Vagyis nincs egyetemes jólét, mert nincs olyan sok, ami mindenkinek elegendő, mint ahogyan nem létezik olyan gazdag társadalom, amelyik azt mondja, hogy elegendő, ami van, nem kell több (Kováts-Németh, 2010). 
„A Termelj, fogyassz, cseréld újra propaganda tudományos módszerekkel valósítja meg a tömegszuggessziót és az emberek manipulálását és a tudományok tudománya az, amely sok pénzt, energiát, vagy mások feletti hatalmat tud biztosítani" (Kováts-Németh, 2010. 62. o.).

A tudomány és a technika mérhetetlen ütemü fejlödése ugyan fokozza emberek kényelemérzetét, és az emberi élet megkönnyítését szolgálja, ugyanakkor mindezzel visszafordíthatatlan lépéseket tesz saját pusztulása felé. A megtett úton olyan emberi értékek csorbulnak vagy tủnnek el, mint a barátság, a szeretet, a megértés, a hüség, a bizalom, az összetartozás. A mai kor embere, a mindennapi hajsza közepette, az önmagával folytatott folyamatos versenyfutásban nem is veszi észre mennyire fásulttá, magányossá, elszigeteltté válik. Sajnálatos módon korunk családi életét a szabály és normák nélküli felszínes kapcsolatok jellemzik. Eltűntek olyan alapvető értékek, mint tisztesség, igazságosság, megbízhatóság, őszinteség.

Az ember erkölcsi magatartásában jelentkező zavar nem csak a jó és a tisztesség - mint érték - emberi magatartásból való eltünését jelenti, hanem ezekkel az alapértékekkel szemben ellenségesen viseltetünk.

A fogyasztói társadalomra jellemző, hogy a termelés mellett a fogyasztás is sokszorosára nőtt, elterjedt az ún. presztízsfogyasztás, mely a társadalmi ranglétrán való valós vagy vélt előbbre jutást biztosíthatja. Kiemelt szerephez jut a pénz, hiszen ez a javak megszerzésének eszköze. Náray-Szabó Gábor szerint az a kiválóbb, akinek több pénze van, és akinek sok pénze van, sokat fogyaszthat. A kompromisszumot nem türö versengés társadalmi feszültségeket generál. Az állandóan változó igényekhez állandóan igazodni kell. Keress többet és fogyassz többet, de az sem nagy baj, ha nem tudsz sokat keresni, hiszen a bankok készséggel állnak rendelkezésre. Vegyél fel kölcsönt, és rögtön a tiéd lehet minden, amire csak vágysz, akár szükséged van ezekre a dolgokra, akár nincs (Náray-Szabó, 2006).

A presztízsfogyasztás mellett megjelenik a konzumizmus, vagyis az a felfogás, mely szerint a társadalom lényege a szolgáltatások, a gyártott és értékesített termékek fogyasztásában rejlik. Fontosak a státusszimbólumok, egy jó márkájú autó, drága ékszerek, márkás öltözék - vagyis fontos az, amit mások látnak (vö. Veblen, 1925).

Gyakran hallhatunk túlfogyasztásról és tévfogyasztásról is. A túlfogyasztás azt jelenti, hogy a fogyasztás mennyisége vagy jellege veszélyezteti az emberi faj életfenntartó rendszerét, túlterheli az életteret, így az már képtelenné válik bizonyos erőforrások megújítására, valamint a keletkező hulladékmennyiség ártalmatlanítására. A tévfogyasztás során az egyes egyének saját jóllétüket veszélyeztetik, például a különbözö függőségek (alkohol, drog) nyomán. A Föld túlterhelése szempontjából a túlfogyasztás lényegesebb probléma, hiszen ökológiai és társadalmi hatásai is vannak, a tévfogyasztás ugyanakkor komoly társadalmi probléma. Éppen ezért kiemelten fontos, hogy a fenntartható 
fogyasztás irányába mozduljunk el. Ehhez szükség van az egyéni felelősségvállalásra, a fogyasztói magatartás tudatos formálására, átalakítására, a környezettudatosság gondolatiságának megismerésére és gyakorlására. Mindaddig azonban, amíg a fogyasztói társadalom elsődleges üzenete az, hogy az ember csak akkor lehet boldogság, ha egyre többet és többet fogyaszt a rendelkezésre álló javakból a jelenleg is fennálló fogyasztási láz nehezen fékezhető, mert mindig újabb igények keletkeznek. Ebben a felfogásban nem igazán törődünk azzal, hogy cselekedeteinknek milyen következményei vannak, valamint, hogy mindezek a következmények milyen hatással vannak az emberekre, a természeti vagy épített környezetünkre. Első lépésként az értékrend megváltoztatására kellene hangsúlyt fektetni, de, ha meggondoljuk, hogy a fogyasztói társadalom egyik alapvető célja a kényelem, vajon mi motiválná az embereket a változtatásra, az önkorlátozásra.

\section{Fenntartható fejlődés?}

A modernkori ember természethez való viszonya gyökeresen megváltozott annak a téves felfogásnak mentén, mely szerint az ember nem érzi magát a természet részének, hanem úgy gondolja, hogy az a küldetése, hogy meghódítsa, leigázza, uralja azt. A tudomány és technika világának vívmányai azt a kényszerképzetet táplálják, hogy az ember képességei korlátlanok, csak az az igazán értékes, ami ember által való és sajnálatos módon nem hajlandó tudomásul venni azt az evidenciát, hogy a természet erőforrásai kimerülnek, hogy a természet pusztítása az ember értelmi és erkölcsi képességeinek lerombolását eredményezi és a természet legyőzésének maga az emberiség lesz a legnagyobb vesztese.

A fenntarthatóság fogalmát többen többféleképpen megfogalmazták amióta Lester Brown A fenntartható társadalom címü könyvében a fenntarthatóságot a népesség növekedése, a társadalom anyagi igényei, a természeti erőforrások felhasználása és a minimális környezetszennyezés közötti összhang megteremtéseként értelmezte (Kováts-Németh, 2010).

A fenntartható fejlődés fogalompár tartalmát és használatát sokan vitatják. A kifejezés ellen az az érv szól, hogy az emberiség jelenleg jóval több erő - és energiaforrást használ, mint amennyit a fenntarthatóság megengedhet, vagyis a jelenlegi gazdasági rendszer csak jelentős többlet-erőforrásokkal tartható fenn. Mivel az erőforrások nem korlátlan mennyiségben és ideig állnak rendelkezésre, máris érezhetőek a válság jelei, mert a technológia jóval gyorsabban fejlődik, mint az emberiség felelösségérzete. Vagyis nem hagyhatjuk figyelmen kívül, hogy a globális környezeti problémák alapvető oka a fogyasztói igények folyamatos növekedése, ami az ún. népesség robbanással és a jólét iránti fokozott igénnyel magyarázható. A Föld lakossága 2012-re elérte a hétmilliárdot, ami négyszer több mint a 100 évvel azelőtti. Ugyanakkor az energiafelhasználás tizenkétszeresére, a vízfogyasztás tízszeresére, a szemétterhelés tízszeresére, míg az árutermelés hússzorosára nőtt. Mindezek alapján a népességrobbanás mellett a fogyasztásrobbanásról is beszélnünk kell (Szarka, 2009). 
A fenntartható fejlődés magában hordozza, „hogy a civilizációs fejlődés eredményeinek összhangban kell lenniük a természeti környezet fennmaradásával, de a fejlődés fenntarthatósága azt is jelenti, hogy tovább fejlödhet a fogyasztói társadalom" (Kováts-Németh, 2010. 181. o.).

Tehát akkor vajon mi is a fejlödés és mit is akarunk fenntartani?

A fogyasztói társadalom fejlődése során az emberek elkényelmesedett életmódja egyre több energiafelhasználással, vízfogyasztással jár, és mindez a környezet lerombolása árán valósítható meg (Szarka, 2009).

A fejlődés fogalma alatt alapvetően gazdasági, anyagi növekedést, tehát mennyiségi gyarapodást értünk, keress és fogyassz minél többet, egyet fizetsz és kettőt kapsz, ha valami elromlik, dobd el és vegyél egy újat.

A fenntarthatóság biztosításának alapja az összhang, az egyensúly, a harmónia az igények és a felkínált lehetőségek között. A gazdaság alapját a természeti erőforrások, az energia, a víz, a talaj képezi, amely véges rendszer, éppen ezért a gazdasági növekedést nem lehet fenntartani a végtelenségig, csak a rendelkezésre álló készletek erejéig.

Mivel a gazdaság forrása a természet, a fejlődés, vagyis a növekedés fenntartása nem más, mint a fenntarthatatlan fenntartása, amely logikailag értelmetlen, következésképpen nem létezik fenntartható növekedés és lehetetlen fenntartható természeti erőforrásokat biztosítani a gazdaság fenntarthatatlan fejlődése számára (Németh, 2013).

A Nobel-díjas Richard Smalley az emberiség elött álló problémák rangsorának felállításakor azokat vette elöre, amelyek megoldása annak feltétele, hogy a sorban utánuk következőkkel érdemben lehessen foglalkozni. Az általa felállított sor elemei az energia, víz, élelmiszer, környezet, terrorizmus és háború, betegség, oktatás, demokrácia és népesség. Végiggondolva ezeket a problémákat nyilvánvalóvá válik, hogy azért az energia a legalapvetőbb, mert az „,időegység alatt elérhető energia mennyisége alapvetően behatárolja mindenféle emberi tevékenység lehetőségét, még a víznyerését is. Az energia és a víz együttes alapfeltételeit jelentik az élelmiszertermelésnek, azaz a talaj hasznosításának. Ha nincs elegendő energia, víz és élelmiszer (talaj) értelmetlen bármiféle környezeti kérdésről beszélni. A társadalom müködésének feltétele pedig éppen e négy tényező. A Föld energiaforrásai és nyersanyagkincsei, víz-és talajkészletei iránti igény egyre nő, és ennek oka a népesség növekedése, valamint az egyre inkább eluralkodó globális fogyasztói szemlélet. A fenntarthatóság legnagyobb akadályát tehát éppen az a fogyasztói társadalom jelenti, amelynek döntéshozói a fenntarthatóság fontosságát hirdetik" (Szarka, 2009. 45. o.).

Lányi András véleménye szerint az a meghatározás, hogy: ,a fejlődés akkor fenntartható, ha a ma élők úgy elégítik ki szükségleteiket, hogy ezzel nem akadályozzák az utánuk jövőket abban, hogy ugyanezt majd ők is megtehessék" (Lányi, 2010. 12. o.) több szempontból is vitatható. Egyrészt a fenntarthatóság és a szükségletek nem állnak ennyire közvetlen módon kapcsolatban egymással, 
illetve a jövő nemzedékeinek szükségleteit nem láthatjuk előre. A jelenkor emberét vizsgálva sem a szükségletek, hanem azok kielégítési módja veszélyezteti környezetünket, kultúránkat, emberi kapcsolatainkat, egészségünket. Éppen ezért a szükségletek helyett inkább a jövő nemzedék jogairól lenne érdemes beszélni, hiszen ,az emberiség közös öröksége, a földi élővilág változatossága, a nemzedékről nemzedékre gyarapodó tudás, ami megilleti őket” (Lányi, 2010. 14. o.).

A fenntartható fejlődés, mint fogalom pedig azért felesleges, mert az élő rendszerekben lezajló folyamatok csak addig tartanak, ameddig a rendszerek megújulásához szükséges erőforrások a növekedéssel legalább arányos, de jobb, ha annál nagyobb mértékben állnak rendelkezésre. Vagyis addig fejlődés a fejlödés, amíg fenntartható.

Gyulai Iván a fenntarthatóság feltételeit a folyamatos jobblét megvalósításában, az emberek alapvető szükségleteinek kielégítésében, az erőforrásokból származó haszon igazságos elosztásában, az erőforrások fenntartható és az eltartóképesség szerinti használatában, a környezetminőség biztosításában látja (Hofmeister, Kelemen és Piskóti, 2009).

A fenntarthatóság tehát elképzelhetetlen a gazdaság, a társadalmi viszonyok valamint a természeti erőforrások összehangolt fenntartható müködtetése nélkül.

\section{A környezetetika szükségessége}

A környezetetika kiindulópontja, hogy az emberiség jelenlegi cselekedetei hatással leszek a későbbi generációk életére, és olyan kérdésekre keresi a választ, hogy hogyan kell élnünk és vajon meddig mehetünk el a minket körülvevő környezet átalakításában, és vajon hajlandóak vagyunk-e saját érdekeink érvényesítésének korlátozására a természet, környezetünk érdekében.

A környezetetikák általában három csoportba sorolhatók attól függően, hogy mit tekintenek önértékkel rendelkezőnek és ezzel együtt a legfontosabb megvédendő értéknek. Az antropocentrikus szemlélet kizárólag az embert, a biocentrikus szemlélet az egyes élölényeket és magát az életet is, az ökocentrikus szemlélet pedig az ökoszisztémát tekinti morális státusszal rendelkezőnek. Az antropocentrikus környezeti etikák éppen azt a felfogást erösíthetik, hogy a környezet kihasználható, károsítható amennyiben az ember érdeke ezt kívánja, vagyis a természetet nem tekinti értéknek. Amennyiben azt hangsúlyozzuk, hogy az ember a természet része, és a környezet pusztítása önmaga ellen is történik, ez a szemlélet nem segíti a felelős, környezettudatos magatartás kialakítását.

A biocentrikus etikák esetében pozitív az a gondolat, hogy minden élölény élete fontos és nem az emberért léteznek, de nem hagyható figyelmen kívül, hogy a jelenleg tapasztalható biodiverzitás-csökkenés nem egy-egy élőlényről szól.

Az ökocentrikus etikák esetében az ökoszisztéma védelme kulcsfontosságú, ám az egyéni és közösségi érdek összevetésekor vajon akkor is védenünk kell-e az egyéni érdeket, ha az egy egész faj kipusztulását eredményezheti (Kovács, 2009). 


\section{A fenntartható megélhetés alapjai}

A fenntartható megélhetés legalapvetőbb kérdése az ember munkához való viszonya. A munkavégzés során értékeket állítunk elő bizonyos anyag- és energiamennyiség felhasználásával, és e tevékenység során az előállítás és lebontás, a termelés és fogyasztás egységének és egyensúlyának megteremtését kell szem előtt tartani. A termelés során lehetőség szerint csökkenteni kell a költségeket és bár növelni kell a hatékonyságot és nyereséget is kell termelni, ám mindeközben nem feledkezhetünk el arról, hogy az ember a természet része, így figyelmet kell fordítani a természet, a környezet megóvására, a környezet és az ember egészségének védelmére. Etikai szempontból úgy fogalmazhatnánk, hogy a fenntartható megélhetés alapja a mértékletesség. A társas lét ökologikus szerveződése éppen ehhez nyújt megfelelő alapot. E szerveződési formában fontos a generációk egymáshoz való viszonya, a társas támogatás, az ember alkotóképességének az élet szolgálatába állítása.

A fogyasztói társadalomban a munka a pénzszerzés eszközévé válik és a legföbb erkölcsi norma a mértéktelenség. A társadalmi lét atomisztikus szerveződése a többlettermelést, a javak felhalmozását, a pazarlást támogatja. A valódi értékek, mint a tisztelet, szeretet, az erkölcsi alapelvek betartása, a közösségi élet javítása nem érték. Az erőszak, a szélsőséges verseny, a kapzsiság, a természetrombolás közben az emberi kapcsolatok, a szellemi - lelki kötődések egyáltalán nem fontosak.

Tehát a fenntartható megélhetés - etikai vonatkozásban - feltételezi az ember és a természeti folyamatok önértékként kezelését. Az ember vonatkozásában ez az egyének és a közösségek autonómiájának tiszteletét jelenti, míg a természet, önértékkénti értelmezése annak megértését feltételezi, hogy a természet nem egyszerűen egy erőforrás, hanem önmagában érték (Nánási, 2005).

\section{A fenntartható fogyasztás}

A fenntartható fogyasztás fogalma az 1992-ben Rio de Janeiróban megrendezett ENSZ Környezet és Fejlődés Konferenciáján fogalmazódott meg. A fenntartható fogyasztás megteremtése a modernkori társadalmak előtt álló egyik kulcsfontosságú feladat, mely az életminőség javítására, az egyéni és társadalmi jólét egyidejü biztosítására irányul. A fenntartható fogyasztás nemcsak arról szól, hogy a megtermelt javakból kevesebbet fogyasszunk, hanem arról, hogy tudatosabban, megfontoltabban, hatékonyabban szemléljük a fogyasztásunkat. Nem arról van szó, hogy mondjunk le a mindennapi szükségleteinkről, hanem csak annyi és olyan termékeket és szolgáltatásokat fogyasszunk, melyek megfelelnek az alapvető igényeinknek, megfelelő életminőséget biztosítanak, de mindezek mellett minimálisra csökkentjük a természeti erőforrások, a szintetikus, mérgező anyagok használatát, a hulladéktermelést, a környezetszennyezést. Mindezzel együtt vegyük figyelembe egy-egy termék vagy szolgáltatás teljes életciklusát, elkerülve a korábban már említett túlfogyasztást. 
Valkó szerint a fenntartható fogyasztás során nemcsak a fogyasztási szokásainkon kell változtatnunk, hanem egy újfajta értékrendet - a fenntarthatóságot szolgáló fogyasztói magatartásmintát - kell kialakítanunk és követnünk (Valkó, 2003).

Ahogy Rieger László fogalmaz: „A fenntartható életmód, fogyasztás és termelés együttesen biztosítja a társadalmi-gazdasági fejlődés és környezetterhelés szétválását, azaz, hogy a lakosság növekvő jólléte csökkenő környezetterhelés mellett legyen biztosítható" (Rieger, 2011. 67. o.).

A fogyasztói magatartás szociális tanulás útján alakul ki, sokféle hatás eredményeképpen az emberek megismerik a fogyasztási javakat, a szolgáltatásokat, a környezeti értékek, attitüdök és cselekvési minták követése vezet a tényleges cselekvésig.

A fogyasztói magatartás megváltoztatása, a fenntartható termelés forrástakarékossága, a környezetre gyakorolt káros hatások csökkentése, a termékek, szolgáltatások felértékelődése olyan célok, melyek egyértelmüen szükségessé teszik a társadalom környezettudatosságának erősítését (KovátsNémeth, 2011).

A társadalmi, gazdasági és környezeti problémák összehangolt megoldása csak egy megváltozott szemléletü társadalomban, a holisztikus megközelítés előtérbe helyezésével képzelhető el. A társadalom környezettudatosságának formálásában az oktatás és nevelés kiemelt jelentőséggel bír.

\section{A fenntarthatóság pedagógiája}

Az ENSZ 1992-es Környezet és Fejlődés Világkonferenciája (Föld Csúcstalálkozó) az Agenda 21-ben hangsúlyozza a nevelés szerepét egy olyan fejlődés megvalósítása érdekében, amely tiszteli és gondozza a természetes környezetet. A nevelésnek ösztönöznie kell a természet tiszteletéhez kapcsolódó értékek és hozzáállás megismerését, és támogatni kell az elsajátítás útjait és módjait.

A johannesburgi csúcstalálkozó (2002) idejére a korábbi elképzelés kiegészült a társadalmi igazságosság, a szegénység elleni küzdelem, a szolidaritás, egyenlőség, partnerség és együttmüködés kérdéskörével is. Meghirdették a Fenntarthatóságra Nevelés Évtizedét, ami egyértelmü bizonyítéka, hogy a nevelés, és tanulás a fenntarthatóság egyik központi kérdése.

Az Agenda 21 36. fejezete hangsúlyozza, hogy a nevelés kulcsfontosságú a fenntartható fejlődés megvalósítása és az emberek környezeti és fejlődési témák megértési képességének javítása érdekében.

A fenntarthatóság pedagógiája olyan alapértékek érvényre jutását segítheti, mint: az emberek jogainak és méltóságának tisztelete, elkötelezettség a teljes körü társadalmi-gazdasági igazságosság valamint a nemzedékek közötti felelősségvállalás mellett, az élőlények nagyobb közösségének, és azok sokféleségének tisztelete, óvása, a földi ökoszisztémák megörzése és helyreállítása, valamint a 
kulturális sokféleség tisztelete, elkötelezettség a tolerancia, erőszakmentesség és békehelyi és globális kultúrája mellett (ENSZ).

Az ENSZ egy teljes évtizedet szentel arra, hogy az oktatás minden szintjén érvényesülhessenek a fenntarthatóság alapelvei. A nevelés - oktatás fó céljait „A tanulás a fenntartható fejlődés érdekében" stratégia tartalmazza, mely szerint a tanulás kritikus gondolkodásra bátorít, ösztönzi a problémamegoldást, a mindennapi életben alkalmazható, használható tudást nyújt. A stratégia sikeres megvalósításához holisztikus megközelítés, kritikai, kreatív gondolkodás, kompetenciafejlesztés szükséges. A fenntarthatóságra nevelés a nevelési-oktatási folyamat átértékelését, megújulását feltételezi. A fenntarthatóság pedagógiája igyekszik közelebb hozni a valós életet az iskolához, felismerteti a tanulókkal a természeti, társadalmi, gazdasági problémákat, az ok-okozati összefüggéseket, és olyan felhasználható ismereteket közvetít, melyek hozzájárulnak a felelös állampolgárrá neveléshez ráirányítva a tanulók figyelmét a természeti erőforrások védelmére, a velük való ésszerü gazdálkodásra, a fenntartható fogyasztásra (Kováts-Németh, 2010).

A modern társadalomban az évtizedek folyamán kialakult értékek, magatartásminták, normák átörökítése sérült és ez gátló tényezőként hat az érett felelősségteljes személyiség kialakulására. Mindez azért jelent komoly problémát, mert a fogyasztói társadalomban jelentkező globális kihívásokra, csak egy felelős, döntésképes, szabad, önálló ember tud válaszolni. Olyan emberről beszélünk, ,aki:

- képes felismerni a szükségleteit, és azok kielégítésében képes mértéket tartani,

- úgy valósítja meg önmagát, hogy egyéni szabadságának korlátokat szab,

- embertársaival akar és tud együttmunkálkodni, de saját cselekedeteiért felelősséget vállal,

- az együttmüködés során a fegyelmezettség, rend, a szabályok betartása alapvetö,

- a környezetröl alapvető ismeretei vannak,

- a természetet nem uralni akarja,

- az „emberi környezetért” munkálkodik” (Kováts-Németh, 2010. 194-195. o.).

\section{Nevelés és oktatás a fenntarthatóságért - az ökoiskola szerepe}

$\mathrm{Az}$ UNESCO jelentős szerepet vállalt egy nemzetközi iskolahálózat létrehozásában, amelyben a fenntartható fejlődést szolgáló oktatási folyamatot megfelelő kritériumrendszer támogatásával képzeli el. E kritériumok a felelősségvállalást, a problémák felismerését, a helyi értékek megismerését és megőrzését, a tanulóközpontú tanulás biztosítását, az emberi jogok tiszteletben tartását, az egészségnevelést, a természeti erőforrások védelmét, a fenntartható fogyasztás megismertetését is magukban foglalják.

Az ökoiskolai cím elnyeréséhez alkalmazott feltételrendszer pontosan körülhatárolja a feladatokat és a nevelés - oktatás felelösségét. Ennek értelmében: 
- a fenntarthatóságra nevelés koncepciója az iskola nevelésfilozófiájával, arculatával összhangban álló,

- az iskolai alapdokumentumokban meg kell jelennie a fenntarthatóságra nevelés iskolai célrendszerének, feladatainak,

- biztosítani kell az iskolahasználók - más szóval - az iskola partnereinek együttmüködési formáit,

- a pedagógiai kultúra megújulását bizonyító korszerű tanóraszervezési tanulásirányítási módszereket kell alkalmazni a pedagógiai munka megszervezésekor,

- a lehetőségekhez mérten mindent meg kell tenni a környezetterhelés csökkentése érdekében, a környezet javítása és gazdagítása érdekében,

- az iskola találjon módot nevelési eszméi és azok megvalósulása eredményeinek disszeminációjára,

- jöjjenek létre külső partnerekkel konkrét tevékenységekben realizálódott együttműködési megállapodások,

- az iskola fenntarthatóságra nevelési tevékenysége illeszkedjen a település ez irányú törekvéseihez

(Kováts-Németh, 2010, 113-114.o.)

A gyakorlóiskolában a tanulók környezettudatosságának és egészségmagatartásának fejlesztésére irányuló nevelőmunka szerteágazó tevékenységek soráról árulkodik. Az egyes tantárgyak és tanórák- magyar, természettudományos tárgyak, technika, osztályfőnöki óra- kínálta lehetőségek kihasználásán túl e terület ápolása és fejlesztése a következők szerint is csoportosítható:

\begin{tabular}{|c|c|c|}
\hline $\begin{array}{l}\text { Természetes környezet/ } \\
\text { Környezetvédelem/ } \\
\text { Természetvédelem }\end{array}$ & $\begin{array}{l}\text { Épített és társadalmi } \\
\text { környezet védelme }\end{array}$ & $\begin{array}{l}\text { Egészségnevelés/ } \\
\text { Egészséges életmód }\end{array}$ \\
\hline 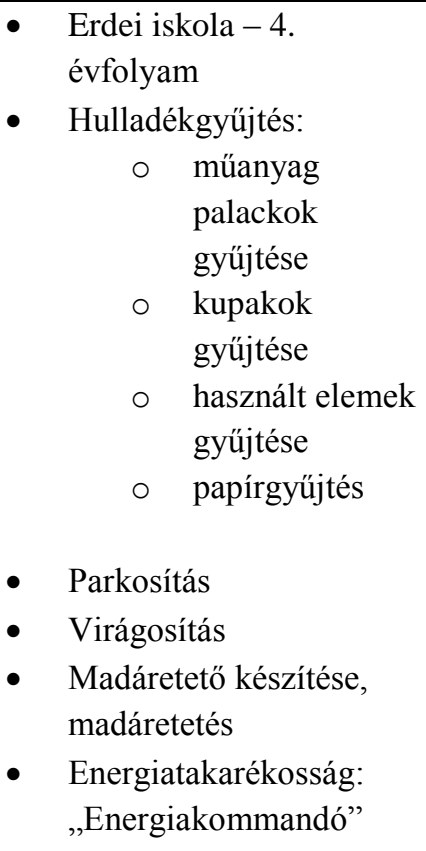 & 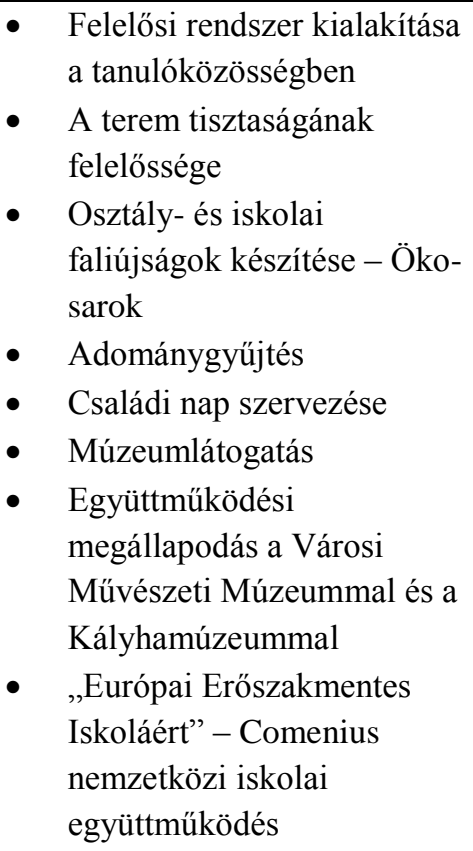 & $\begin{array}{ll}\text { - } & \text { Napi higiénia } \\
\text { - } & \text { Fogápolás } \\
\text { - } & \text { Helyes testtartás } \\
\text { - } & \text { Kamanvizsgálatok } \\
\text { - } & \text { Eelki változások, higiénia } \\
\text { - } & \text { Egészsséges étkezés, } \\
\text { étkezések rendje, } \\
\text { illemtana - Egészségnap } \\
\text { - Gyümölcsfogyasztás - } \\
\text { „almaakció”, } \\
\text { - } \text { gyümölcssaláta készítése } \\
\text { Egészséges büfé } \\
\text { Évszaknak megfelelö } \\
\text { öltözködés } \\
\text { Testmozgás fontossága- } \\
\text { mindennapos testnevelés, }\end{array}$ \\
\hline
\end{tabular}




\begin{tabular}{|c|c|c|}
\hline & $\begin{array}{l}\text { eredményeként - } \\
\text { „Erőszakmentes iskola” } \\
\text { elismerés } \\
\text { • Comenius nemzetközi } \\
\text { iskolai együttmüködés a } \\
\text { diákönkormányzatért } \\
\text { •Pedagógia a színpadon - } \\
\text { drámapedagógiával az } \\
\text { erőszak ellen” } \\
\text { Bűnmegelőzési } \\
\text { előadássorozat } \\
\text { Együttműködés a } \\
\text { Közlekedésbiztonság } \\
\text { Fejlesztő Intézettel - Ki a } \\
\text { bajnok két keréken?- } \\
\text { kerékpáros igazolvány } \\
\text { megszerzése }\end{array}$ & $\begin{array}{l}\text { korcsolyázás, } \\
\text { kerékpártúrák } \\
\text { Együttmüködés a } \\
\text { „kajakosokkal”- } \\
\text { sárkányhajó túra } \\
\text { - Kirándulás }\end{array}$ \\
\hline „Világnapok” megünneplése & & \\
\hline
\end{tabular}

\section{A projektoktatás módszerei}

A személyiségformálás a pedagógiai tevékenység elsődleges feladata. A napjainkban oly gyakran emlegetett pedagógiai kultúra megújulásához a reformpedagógiai modellekhez kellene visszanyúlnunk, hiszen a reformpedagógia az iskolarendszer radikális megváltoztatását és a gyermek fejlődési sajátosságaival összhangban álló nevelési módszerek alkalmazását tartja elsődlegesnek, ahol fontos a gyermeki szabadság; az önkibontakozás, a gyermekek aktív részvétele, a változatos önálló gyermeki tevékenységek biztosítása, a tanárszerep újragondolása.

A projektoktatás során alkalmazott módszereket három csoportba sorolhatjuk, és e csoport mindegyikéhez meghatározott feladatok és eszközök rendelhetők (Kováts-Németh, 2010).

\begin{tabular}{|l|l|}
\hline \multicolumn{1}{|c|}{ Módszer } & \multicolumn{1}{c|}{ Feladatok, eszközök } \\
\hline hangos gondolkodás & $\begin{array}{l}\text { döntések elökészítése, felidézés, } \\
\text { problémafelvetés }\end{array}$ \\
\hline fogalomtérkép & $\begin{array}{l}\text { elözetes ismeretek feltárása, } \\
\text { kulcsszavak gyüjtése }\end{array}$ \\
\hline rendezett fa & logikai önellenörzés \\
\hline beszélgetés & kölcsönös kérdésfeltevés \\
\hline tanulói kiselőadás & $\begin{array}{l}\text { olvasmányélmény, internetes } \\
\text { böngészés }\end{array}$ \\
\hline elbeszélés & élmények felidézése \\
\hline
\end{tabular}

Személyes célok megismerését elősegítő módszerek (vö. Kováts-Németh, 2010. 231. o.) 


\begin{tabular}{|l|l|}
\hline \multicolumn{1}{|c|}{ Módszer } & \multicolumn{1}{c|}{ Feladatok, eszközök } \\
\hline kutatás & $\begin{array}{l}\text { alkotás, célok, problémák } \\
\text { meghatározása }\end{array}$ \\
\hline megfigyelés & adatgyüjtés, jegyzetelés \\
\hline elemzés & $\begin{array}{l}\text { tartalomelemzés, szövegelemzés, } \\
\text { kivonatolás, rendszerezés }\end{array}$ \\
\hline házi feladat & önálló adatgyüjtés, kiselöadás \\
\hline
\end{tabular}

Az önállóságot, kreativitást, kutatást elősegítő módszerek (vö. Kováts-Németh, 2010. 239. o.)

\begin{tabular}{|l|l|}
\hline \multicolumn{1}{|c|}{ Módszer } & \multicolumn{1}{c|}{ Feladatok, eszközök } \\
\hline projektmódszer & feladatelosztás, kivitelezés, bemutatás \\
\hline kooperatív eljárások & csapatépítés \\
\hline játék & szerepjáték, szituáció, helyzetgyakorlat \\
\hline rendezvények szervezése & $\begin{array}{l}\text { vetélkedők, kiállítások szervezése, } \\
\text { plakátok, poszterek }\end{array}$ \\
\hline
\end{tabular}

4. táblázat:

Az együttmüködést feltételező módszerek (vö. Kováts-Németh, 2010. 246. o.)

\begin{tabular}{|c|c|c|c|}
\hline $\begin{array}{l}7 . \\
\text { osztály }\end{array}$ & $\begin{array}{l}\text { Fenntartható } \\
\text { fogyasztás- } \\
\text { az étkezés } \\
\text { környezeti } \\
\text { hatásainak } \\
\text { megismerése }\end{array}$ & $\begin{array}{l}\text { A tanulókkal összegyűjtjük, } \\
\text { hogy ők milyen tényezők, } \\
\text { jellemzők alapján választják } \\
\text { ki az általuk fogyasztott } \\
\text { élelmiszereket. } \\
\text { A gyerekek csoportokban az } \\
\text { élelmiszervásárlás környezeti } \\
\text { hatásait ismerik meg. } \\
\text { A csoportok beszámolnak az } \\
\text { általuk megszerzett } \\
\text { információkról - élelmiszer- } \\
\text { kilométer, szezonális } \\
\text { élelmiszerek, természetes } \\
\text { élelmiszerek természetes } \\
\text { hibái, csomagolás, } \\
\text { tápanyagok bevitele, } \\
\text { tápanyagok egyensúlya } \\
\text { A tanultak rögzítése - } \\
\text { „szabálykönyv” alkotása }\end{array}$ & $\begin{array}{l}\text { A személyes célok } \\
\text { megismerését elősegítő } \\
\text { módszerek: beszélgetés } \\
\text { Az együttműködést } \\
\text { feltételező módszerek: } \\
\text { szakértői mozaik (kooperatív } \\
\text { eljárás) } \\
\text { Az együttműködést } \\
\text { feltételező módszerek: } \\
\text { csoportforgó (kooperatív } \\
\text { eljárás) }\end{array}$ \\
\hline
\end{tabular}

5. táblázat:

Fenntartható fogyasztás 


\begin{tabular}{|c|c|}
\hline $\begin{array}{c}\text { Fenntarthatóság, környezettudatosság } \\
\text { Fejlesztési területek nevelési célok } \\
\text { NAT } 2012 \text { 8-9. o. alapján }\end{array}$ & $\begin{array}{c}\text { Természettudományos kompetencia } \\
\text { NAT } 2012 \text { 19. o. alapján }\end{array}$ \\
\hline $\begin{array}{l}\text { Az életformák gazdag változatosságának } \\
\text { - a természetben és a kultúrában - } \\
\text { megbecsülése } \\
\text { Az erőforrások tudatos, takarékos és } \\
\text { felelősségteljes, azok megújulási } \\
\text { képességeire tekintettel való használata } \\
\text { A természet és a környezet ismeretén és } \\
\text { szeretetén alapuló környezetkímélő, } \\
\text { értékvédő, a fenntarthatóság mellett } \\
\text { elkötelezett magatartás kialakítása } \\
\text { A környezettel kapcsolatos állampolgári } \\
\text { kötelességek és jogok gyakorlása } \\
\text { A válságokat elöidézö gazdasági és } \\
\text { társadalmi folyamatok megismerése } \\
\text { A közvetlen és tágabb környezet } \\
\text { értékeinek, sokszínüségének megőrzése, } \\
\text { gyarapítása }\end{array}$ & 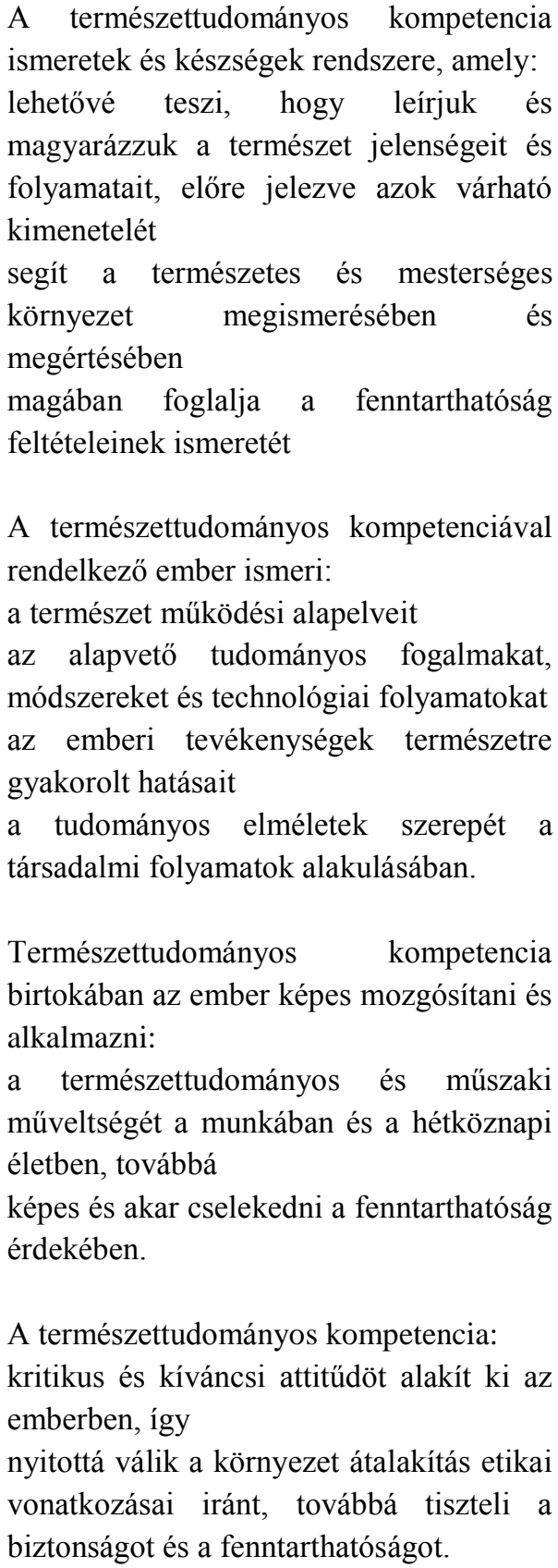 \\
\hline
\end{tabular}

A Nemzeti alaptanterv fejlesztési feladatai alapján a nevelés - oktatás az autonóm személyiség kialakítását tartja fontosnak. Az autonóm személyiség nyitott a természeti, gazdasági, társadalmi folyamatok soktényezős rendszere iránt. A nyitottság a tolerancia alapja, a toleráns személyiség pedig a természet, a kultúra, az egyének sokféleségét értékként kezeli. Mindehhez szilárd belső értékrendre van szükség, amelynek szerves része az empátia. Az értékrend 
kialakulásában a család, az iskola, a kortárscsoportok, de a média, a tömegkommunikáció is komoly szerepet játszik, ám felsorakoztatott elemek nem biztos, hogy ugyanazokat az értékeket közvetítik. Felmerül tehát az az etikai kérdés, hogy a néha talmi, vagy álértékek között el tudunk-e igazodni, és hogyan segíthetjük tanítványaink eligazodását. A környezetünk értékeinek megörzéséért felelősséget vállalni tudó ember alkotni képes és szándékozó személyiség, ami etikai szempontból azt jelenti, hogy el tudja dönteni részt kíván-e venni a problémák megoldásában, a döntéselökészítésben (Nánási, 2005).

A NAT e fejlesztési területe összhangban áll a Fenntarthatóságra Nevelés Évtizedének célkitűzéseivel.

A nevelés-oktatás küldetése többek között a természettudományos kompetencia kialakítása annak érdekében, hogy segítse az emberi tevékenység természetre gyakorolt hatásának megismerését. Amennyiben ez igaz, nem hagyhatjuk figyelmen kívül olyan részigazságokat tartalmazó tananyagtartalmak nyomtatásban való megjelenését, amelyek azt közvetítik a tanulók számára, hogy a megújuló energiaforrások használata a környezetünket ugyan nem rombolja, de az emberek lehetőségei e területen nem ütköznek korlátokba (Kapai, 2013). Vagyis akkor mire is tanítjuk a gyerekeket? Mértékletességre? Mértéktelenségre?

\section{Befejezés}

A modernkori társadalmak folyamatosan emelkedő népessége, a megállíthatatlan gazdasági növekedés, a technológia rohamos fejlödése nyomán az ember olyan mértékben alakítja át környezetét, mely akár tönkre is teheti azt. Kutatások igazolják, hogy a legnagyobb veszélyt nem a népesség növekedése, hanem a fogyasztásrobbanás okozhatja, amely a korlátozott mértékben rendelkezésre álló nyersanyag- és energiaforrások kimerüléséhez és visszafordíthatatlan környezetszennyezéshez vezethet.

Az egyre inkább eluralkodó fogyasztási láz nehezen fékezhető, hiszen minden egyes igény kielégítése egy-egy újabb igényt generál. A napjainkban oly divatos szóval megfogalmazott fenntartható fogyasztás nem egyenlő a környezetbarát termékek fogyasztásával. Sokkal összetettebb jelenséggel állunk szemben: az embereknek másfajta fogyasztói magatartást és az eddigiektől eltérő szokásrendszert kell kialakítaniuk és követniük. A szemléletformálódás következményeképpen az emberi szükségletek kielégítése, az elfogadható életminőség és életszínvonal megléte az erőforrások tudatos, gazdaságos felosztása, a felnövekvő nemzedék jogainak fegyelembevétele és a Föld bolygó környezetterhelésének csökkentése mentén valósulhat meg. E szemléletformálásban kiemelt szerepet játszik a család, mint elsődleges szocializációs közeg, de természetes nagy feladat hárul a nevelés-oktatás szakembereire, a médiára, a politikai döntéshozókra, a termelésben résztvevőkre, a szolgáltatókra vagyis mindannyiunkra. Közös problémánkra csak közösen találhatjuk meg a megnyugtató megoldást. 


\section{Irodalom}

ENSZ Tanulás a Fenntarthatóságért Évtizedének honlapja: http://portal.unesco.org/education/en/ev.phpURL_ID=27234\&URL_DO=DO_TOPIC \&URL_SECTION=201.html

Hofmeister Ágnes, Kelemen Kata és Piskóti Marianna (2009): Fogyasztói magatartásminták változása a fenntarthatóság tükrében. Marketing Oktatók 15. Konferenciája. Fenntartható fogyasztás. Kaposvár.

Kapai Éva (2013): Útravaló. Erkölcstan 5. Mozaik Kiadó, Szeged.

Kovács József (2008): Környezeti etika. Világosság 49., 9-10.

Kováts-Németh Mária (2010): Az erdőpedagógiától a környezetpedagógiáig. Comenius, Pécs.

Kováts-Németh Mária (2010): Az erdöpedagógiától a környezetpedagógiáig. Comenius, Pécs.

Kováts-Németh Mária (2011): Együtt a környezetért. Palatia Nyomda, Győr.

Lányi András (2010): Miért fenntarthatatlan, ami fenntartható? In: Lányi András és Farkas Gabriella (szerk.) Miért fenntarthatatlan, ami fenntartható?L'Harmattan Kiadó - Budapesti Corvinus Egyetem Környezettudományi Intézete, Budapest.

Nánási Irén (2005, szerk.): Humánökológia. Medicina Kiadó, Budapest.

Náray-Szabó Gábor (2006): Fenntartható a fejlődés? Akadémiai Kiadó, Budapest.

NAT 2012.

Németh Viktória Mária (2010): Környezeti tényezök hatása a fogyasztásra. http://lmv.hu/node/5176 (2013.03.22)

Rieger László (2011): Stratégiák - feladatok a környezet védelméért. In: Kováts-Németh Mária (szerk.) Együtt a környezetért. Palatia Nyomda, Győr.

Szarka László (2009): Globális kihívások „A Föld Bolygó Nemzetközi Éve” szemszögéböl. In: Fenyvesi Ottó (szerk.) MTA VEAB Tudományos előadások 2009. MTA VEAB, Veszprém, 31-49.

Valkó László (2003): Fenntartható/környezetbarát fogyasztás és a magyar lakosság környezeti tudata. In: A Budapesti Közgazdaságtudományi és Államigazgatási Egyetem Környezettudományi Intézetének tanulmányai, Budapest, 2003. április 18. szám.

Veblen, Thorstein (1925): The Theory of the Leisure Class. George Allan and Unwin, London. 